Arch. Mikrobiol. 81, 45-49 (1972)

(C) by Springer-Verlag 1972

\title{
Aplanochytrium kerguelensis gen. nov. spec. nov., a New Phycomycete from Subantarctic Marine Waters
}

Günther Bahnweg and Fredfrick K. Sparrow, JR.

Department of Botany, University of Michigan, Ann Arbor, Michigan, U.S.A.

Received August 10, 1971

Summary. A new monocentric marine fungus, Aplanochytrium kerguelensis gen. nov. spec. nov., was recovered from water samples taken in the vicinity of the Kerguelen Islands in the South Indian Ocean during a cruise of the research vessel USNS "Eltanin". Aplanochytrium is very similar to Thraustochytrium Sparrow (1936) in having a chytrid-like thallus and in being able to utilize pine pollen as a substrate to which it establishes contact by well-developed rhizoids. At maturity, however, only aplanospores are formed, as in Dermocystidium sensu Goldstein and Moriber (1966).

\section{Methods}

Water samples were taken with Niskin Butterfly Biosamplers which yielded an uncontaminated sample of approximately 4 liters of seawater per sampler. Aliquots of 1 liter seawater were filtered through Millipore membrane filters (AAWG 047 00, $0.8 \mu$ pore size). The filters were then transferred to a nutrient agar (tryptone $5 \mathrm{~g}$, yeast extract $2.5 \mathrm{~g}$, glucose $1 \mathrm{~g}$, agar $14 \mathrm{~g}, 1000 \mathrm{ml}$ seawater) and incubated at $8-10^{\circ} \mathrm{C}$ for several weeks.

The nutrient agar was fortified with penicilin $G$ (sodium salt) and streptomycin sulfate (100 mg of each antibiotic per liter medium) to prevent growth of bacteria. Single colonies of fungi were then transferred to antibiotic-free agar plates for purification and isolation. For the purpose of identification and elucidation of life cycles seawater cultures were set up in which pine pollen was used as a bait. Thus, 20 isolates of a fungus displaying characteristics different from any hitherto-described marine phycomycetes were recovered from certain water samples (from depths of $15,25,50,75$, and $90 \mathrm{~m}$, USARP sample No. 526) taken prior to station 17 (USAS "Eltanin" cruise 46) near the Kerguelen Islands (bottom depths $92 \mathrm{~m}$ ). The position of this sampling site was approximately $49^{\circ} 13^{\prime} \mathrm{S}, 71^{\circ} 06^{\prime} \mathrm{E}$; due to failure of navigation instruments it could not be more precisely determined.

\section{Taxonomy}

One of the isolates, number 17-4-I, was chosen to be the type. The fungus differs from the genus Thraustochytrium Sparrow (1936) in that its spores never become flagellated. It differs from Dermocystidium sensu Goldstein and Moriber (1966), which it otherwise closely resembles, in that it forms rhizoids and is able to utilize pine pollen as a substrate. The 


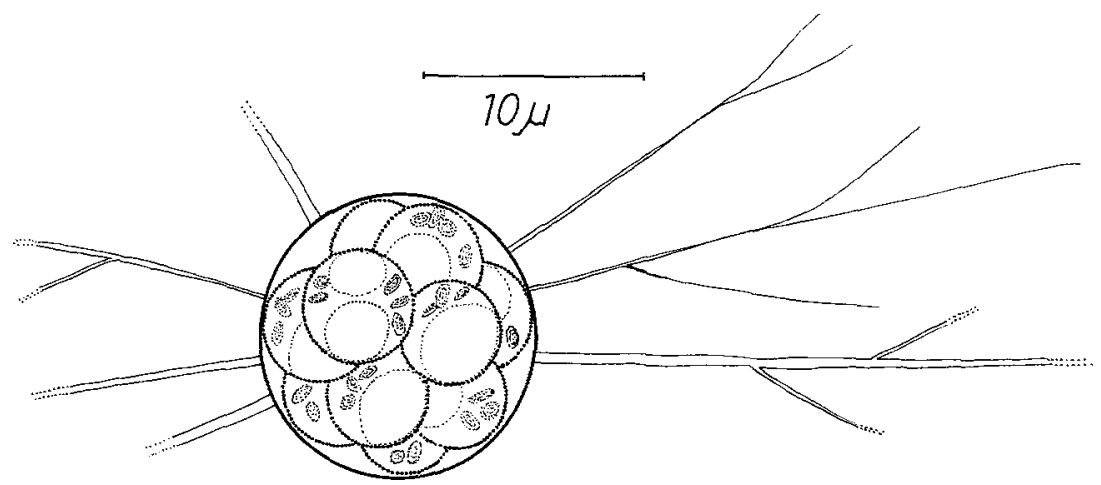

Fig. 1. Aplanochytrium kerguelensis gen. nov. spec. nov., mature thallus displaying vacuolate aplanospores and branched rhizoids

taxonomic diagnosis given below is based on seawater cultures with pine pollen as a bait.

A planochytrium gen. nov. (Fig.1). Sporangia globose or subglobose, sessile or free. Rhizoidal system extensive, branched, endobiotic and exobiotic. Aplanospores only formed.

A planochytrium. Sporangia globosa vel subglobosa, sessila vel libera. Rhizoidale systema extensum, ramosum, endobioticum et exobioticum. Aplanosporae formatae sole.

Aplanochytrium lerguelensis spec. nov. Sporangia epibiotic, sessile or free, smooth, thin-walled, 8-20 $\mu \mathrm{m}$ in diameter, colorless. Aplanospores globose, $1.8-6.5 \mu \mathrm{m}$ in diameter, containing eccentric vacuole and several granules, liberated upon rupturing of the sporangium wall. Occurring in the Subantarctic region of the South Indian Ocean near the Kerguelen Islands.

Aplanochytrium kerguelensis. Sporangia epibiotica, sessila vel libera, levia, paiete tenui, incolorata, $8-20 \mu \mathrm{m}$ in diam. Aplanosporae globosae,

Fig. 2. Young thalli with eccentric vacuoles

Fig. 3. Young sporangium with vesiculate protoplasm

Fig.4. Immature sporangium showing cleavage of the protoplasm

Fig.5. Beginning of aplanospores being liberated; arrows indicate rhizoids on old sporangial wall

Fig.6. Liberation of aplanospores, advanced stage; arrows indicate rhizoids of old sporangial wall

Fig. 7. Sporangium on pollen grain showing endobiotic rhizoids 

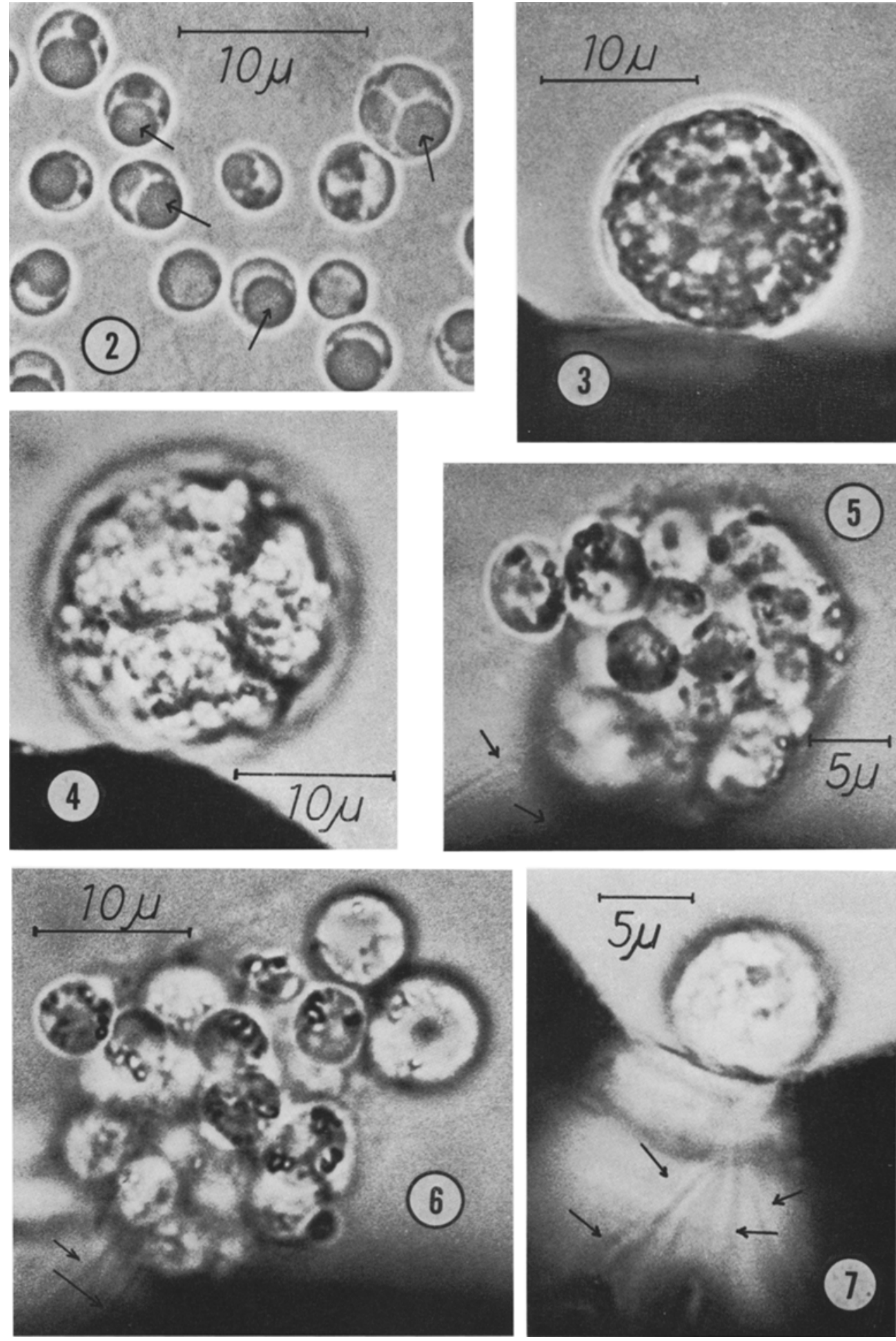

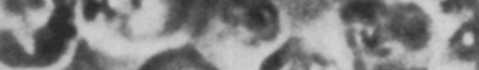

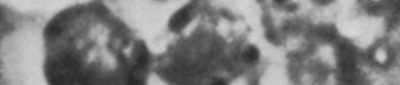

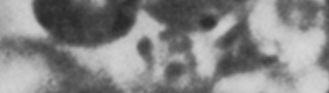

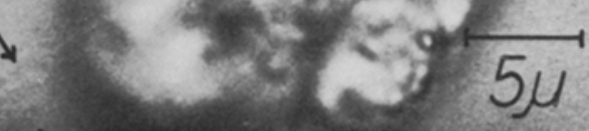

Figs. 2-7 


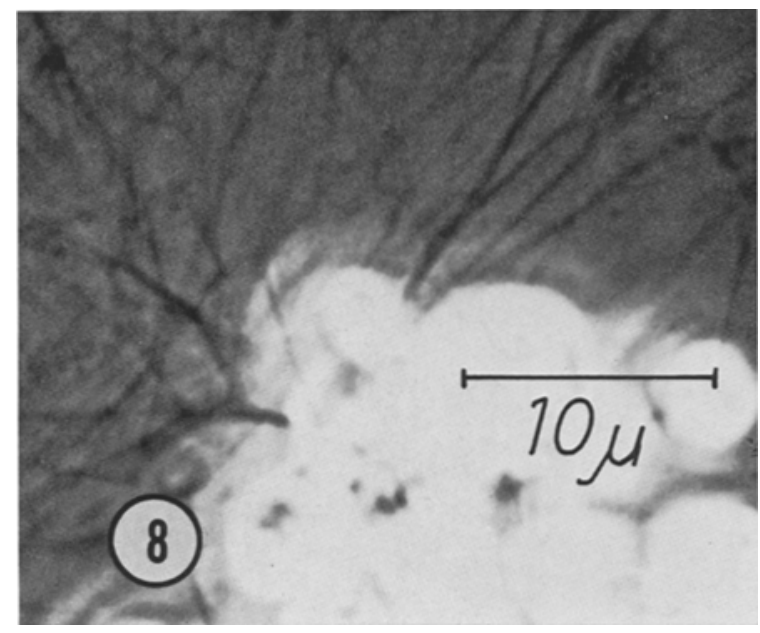

Fig. 8. Cluster of sporangia; note the thicket of rhizoids

$1.8-6.5 \mu \mathrm{m}$ in diam., vacuola ecentrica et aliquot granulis, pariete sporangii rupto liberatae. Habitat in regio subantarctica oceani indici prope insulas kerguelenses.

Type slides and living material available, Botany Department and University of Michigan Herbarium, Ann Arbor, Michigan.

\section{Morphology}

The fungus was inoculated into petri dishes filled with sterile seawater to which heat-sterilized pine pollen was added. The dishes were kept at $15^{\circ} \mathrm{C}$ and samples were examined daily. When the presence of sufficient numbers of thalli was noted (usually after 2 days of incubation) a loopful of seawater with pollen was transferred to a cover glass which was placed sample side down on a slide well filled with sterile aerated mineral oil (the well consisted of an ordinary microscopic slide having a hole of approx. $15 \mathrm{~mm}$ in diameter which was closed at the bottom by a cover glass). The mineral oil sealed the seawater completely preventing evaporation while at the same time providing oxygen. This microculture allowed for uninterrupted observation of single thalli under good environmental conditions for several hours. From such cultures the following description is derived.

The newly emerged globose aplanospores (Fig.5) contain several granules and one or more eccentric vacuoles. The latter become very distinct as the thallus enlarges (Fig.2). Rhizoids from several places on the spore body are formed sometimes as soon as $20 \mathrm{~min}$ after liberation 
of the spores, and these extend in all directions. Thus, those of one thallus may establish contact with several pollen grains. Even when a thallus becomes directly attached to a pollen grain (rhizoids actually penetrating into the pollen grain were observed, Fig. 7) there are usually several other rhizoids either entering the same pollen grain or others (Figs. 5 and 6 ). The immature sporangium continues to increase in size while its protoplasm becomes densely vesiculated and the eccentric vacuoles disappear (Fig.3). Upon attaining full size the protoplasm is cleaved into aplanospores by successive divisions (Fig.4). The mature sporangium contains from a few to 50 aplanospores which become liberated following the rupture of the sporangial wall (Figs. 5 and 6 ). Frequently this wall does not rupture and aplanospores germinate in situ. Sometimes all spores do not leave the sporangium but develop into new thalli inside the old sporangial wall. Thus clusters of sporangia may be formed (Fig.8).

Acknowledgement. This study was supported by a grant from the National Science Foundation (No. GA 16097) through the Office of Polar Programs. We wish to thank Dr. A. Gaertner, Institut für Meeresforschung in Bremerhaven, Germany, for information about the mineral oil technique and Mrs. Evelyn Bahnweg for excellent technical assistance.

\section{References}

Goldstein, S., Moriber, L.: Biology of a problematic marine fungus, Dermocystidium spec. I. Development and cytology. Arch. Mikrobiol. 53, 1-11 (1966).

Sparrow, F. K.: Biological observations on the marine fungi of Woods Hole Waters. Biol. Bull. 70, 236-263 (1936).

Dr. Günther Bahnweg

Department of Botany University of Michigan Ann Arbor, Michigan 48104, U.S.A. 